\title{
14. Education and training: the 2002 NATSISS
}

\section{R.G. (Jerry) Schwab}

The impetus for the first national survey of the Indigenous population, the National Aboriginal and Torres Strait Islander Survey (1994), was the 1991 Royal Commission into Aboriginal Deaths in Custody. This Royal Commission highlighted the lack of a reliable statistical baseline from which to assess the experience of Indigenous Australians (Commonwealth of Australia 1991). The survey followed on the heels of two major policy documents, the Commonwealth Government's Aboriginal Employment Development Policy (AEDP) and the Aboriginal Education Policy (AEP), both of which called for coordinated baseline data and improved education and training outcomes. The results of the 1994 NATSIS were dissected and analysed in a special workshop held at the Australian National University in 1996 (Altman \& Taylor 1996b). Included in the volume of papers from that workshop were specific analyses of the education (Schwab 1996) and training (Daly 1996) components of the survey and findings. This paper picks up the thread of those two earlier critiques in a review of the education and training questions and results of the 2002 NATSISS.

This paper has three principal aims. Firstly, it sets out to contrast the 1994 and 2002 surveys with regard to focus and content related to Indigenous education and training. Specifically, the paper explores what sorts of questions where asked and data collected in 1994 that were not collected in 2002 and, conversely, what new questions and data emerge in the more recent survey. Secondly, the paper summarises the key education and training findings of the 2002 NATSISS. Finally, the paper attempts to assess the value of the education and training components of any future NATSISS and ask, 'Is it really worth all the trouble'?

\section{NATSIS and 2002 NATSISS: what has been lost and gained?}

The 2002 survey is far less ambitious than its predecessor in the areas of education and training. The questions asked of respondents are fewer and consequently the volume of data collected has been reduced. The education and training components of the two surveys are compared in Table 14.1. Specifically, the most recent survey no longer collects data on school participation, where the 1994 survey asked questions about the participation of both preschool and school age children. The earlier survey collected data on parental attitudes and experiences: asking whether parents were happy with the education their children received (and if not, why not); did they feel welcome in the school; 
were they involved in educational decision making at the school; and would they have preferred their children attend an Indigenous community-controlled school. Those questions were eliminated from the 2002 NATSISS. The earlier survey included a series of questions, the answers to which could provide a glimpse of the classroom experience of Indigenous students. It asked whether or not Aboriginal and Torres Strait Islander culture and language were taught in school and whether or not children had Indigenous teachers, education workers or community members in their classrooms. Those questions have also been cut from the most recent survey. While the 1994 survey explored the difficulties and barriers to further study, no such questions appeared in the more recent survey and no data were collected on the distance individuals must travel to access educational institutions.

Table 14.1. Comparison of education and training data collected in NATSIS (1994) and NATSISS (2002)

\begin{tabular}{lll}
\hline & \multicolumn{2}{l}{ Data collected in survey (denoted by ${ }^{*}$ ) } \\
& NATSIS (1994) & NATSISS (2002) \\
\hline School participation (preschool and primary/secondary) & $*$ & \\
Parental attitudes to schooling & $*$ & \\
Characteristics of schooling & $*$ & $*$ \\
Highest level of schooling & $*$ & $*$ \\
Main reason for leaving school & $*$ & $*$ \\
Post-school qualifications & $*$ & $*$ \\
Level and type of post-school study & $*$ & $*$ \\
Type of educational institution currently attending & $*$ & \\
Details of recent training & $*$ & \\
Difficulty/barriers in further study or training & $*$ & \\
Distance to educational institution & & \\
\hline
\end{tabular}

The 2002 survey is consistent with the 1994 version in asking about the highest level of schooling individuals achieved, post-school qualifications, the level and type of post-school study and the type of education institution currently attending. There are, however, some entirely new questions in the 2002 NATSISS that provide additional insight into the experience of education and training for Indigenous people. A particularly useful question asked respondents to indicate the main reason for leaving school (see Table 14.3 below). In addition, individuals are asked to provide more detail in 2002 about the training they received. For example, individuals were asked if their training was provided as part of their participation in the CDEP scheme. Overall, the quantity of information gathered in 2002 is less than in 1994. More has been lost than has been gained, a point I will return to later. 
Table 14.2. Indigenous persons aged 15 years or over, selected education characteristics, Australia, 1994 and 2002

\begin{tabular}{|c|c|c|}
\hline & 1994 & 2002 \\
\hline & $\%$ & $\%$ \\
\hline \multicolumn{3}{|l|}{ Has a non-school qualification } \\
\hline Bachelor degree or above ${ }^{a}$ & 1.2 & 3.3 \\
\hline Certificate or diploma $^{\text {a }}$ & 10.6 & 21.6 \\
\hline Total with non-school qualification ${ }^{a}$ & 11.8 & 24.9 \\
\hline \multicolumn{3}{|l|}{ Does not have a non-school qualification } \\
\hline Completed Year $12^{a}$ & 6.8 & 9.9 \\
\hline Completed Year 10 or Year 11 & 26.9 & 28.8 \\
\hline Completed Year 9 or below ${ }^{a}$ & 43.0 & 35.2 \\
\hline Total with no non-school qualification & 76.7 & 73.9 \\
\hline
\end{tabular}

a. Statistically significant at the $5 \%$ level

Source: ABS (2004c: Table 6)

\section{NATSISS: an overview of findings about education and training}

Table 14.2 compares qualification and highest year of school completed, drawing on the results of the 1994 and 2002 surveys. Overall, the data suggest gains (essentially a doubling) in non-school qualifications at both the degree or above level and the certificate/diploma level over eight years. Less dramatic-but significant nonetheless - is the increase in individuals who report they have no non-school qualification, yet they have completed Year 12. Those figures increased from 6.8 to 9.9 per cent between 1994 and 2002. Interestingly, the 2002 figure is well below the 2001 Census figure of 17 per cent (non-Indigenous Australians reported about double that rate). 
Table 14.3. Indigenous persons aged 15 years or over, main reason left school by remoteness, Australia, 2002

\begin{tabular}{|c|c|c|c|c|c|}
\hline \multirow[t]{2}{*}{$\begin{array}{l}\text { Main reason left } \\
\text { school }\end{array}$} & $\begin{array}{r}\begin{array}{r}\text { Non-remote } \\
\text { female }\end{array}\end{array}$ & Non-remote male & Remote female & Remote Male & Significance test \\
\hline & $\%$ & $\%$ & $\%$ & $\%$ & \\
\hline $\begin{array}{l}\text { Year } 12 \text { or } \\
\text { equivalent not } \\
\text { available }\end{array}$ & 0.6 & 1.5 & 7.5 & 10.5 & $\begin{array}{r}\text { male }^{\mathrm{b}} \\
\text { female }^{\mathrm{b}}\end{array}$ \\
\hline $\begin{array}{l}\text { Got/wanted a } \\
\text { job/apprenticeship }\end{array}$ & 14.5 & 17.5 & 15.7 & 15.8 & \\
\hline $\begin{array}{l}\text { Other } \\
\text { work-related } \\
\text { reason }\end{array}$ & 3.0 & 1.9 & 1.9 & 2.9 & \\
\hline $\begin{array}{l}\text { Feel had done } \\
\text { enough }\end{array}$ & 3.6 & 9.0 & 9.5 & 12.5 & \\
\hline Did not do well & 8.7 & 16.3 & 7.0 & 3.4 & male $^{b}$ \\
\hline $\begin{array}{l}\text { Did not like } \\
\text { school }\end{array}$ & 28.3 & 24.2 & 24.7 & 30.9 & \\
\hline $\begin{array}{l}\text { Other } \\
\text { school-related } \\
\text { reason }\end{array}$ & 10.0 & 13.9 & 8.6 & 9.7 & \\
\hline $\begin{array}{l}\text { Personal/family } \\
\text { reason }\end{array}$ & 25.8 & 11.5 & 20.7 & 8.4 & $\begin{array}{r}\text { non-remote }^{a} \\
\text { remote }^{a}\end{array}$ \\
\hline Other reason & 5.6 & 4.3 & 4.3 & 5.9 & \\
\hline
\end{tabular}

a. The difference between male and female respondents is statistically significant.

b. The difference between remote and non-remote respondents is statistically significant.

Source: Customised cross-tabulations from the 2002 NATSISS

Table 14.3 summarises the findings of a new question. It was asked of people who had not completed Year 12 and who were not, at the time of the survey, currently at secondary school, and it asked the main reason they left school. The table shows the responses from the 2002 NATSISS according to remoteness and sex. There is a great deal of interesting information in the table but I would like to highlight four points. First, the most common reason people gave for leaving school was that they did not like it. The rate was highest among remote males and non-remote females, at about 30 per cent. While one would expect to find some number of students in the general Australian population who left school because they simply did not like it, it is troubling that the proportion is so high among Indigenous people who already attend school at a lower rate than other Australians. Secondly, the survey shows that many people in remote areas (especially males) left because Year 12 was not available in their community. Thirdly, the responses show that in general terms, females were more likely to leave for personal/family reasons. This finding is slightly higher for non-remote females but in both remote and non-remote settings, females were more than twice as likely as males to have left school for that reason. Finally, the survey showed that between 14.5 and 17.5 per cent left school because they 'got/wanted a job/apprenticeship'. Unfortunately, the question was poorly worded and confounds the responses of those who actually left school because they got a job or apprenticeship with those who left because they hoped for such an 
outcome. Obviously, in terms of policy, there is a big difference between getting a job and wanting one.

Table 14.4. Unemployed Indigenous persons aged 15 years or over, main difficulty finding work by remoteness, Australia, 2002

\begin{tabular}{|c|c|c|}
\hline \multirow[t]{2}{*}{ Main difficulty finding work } & Remote & Non-remote \\
\hline & $\%$ & $\%$ \\
\hline Transport problems/distance ${ }^{a}$ & 8.6 & 15.9 \\
\hline No jobs at all ${ }^{a}$ & 29.4 & 8.2 \\
\hline No jobs in local area or line of work ${ }^{a}$ & 18.3 & 10.5 \\
\hline Insufficient education, training or skills ${ }^{\text {a }}$ & 13.4 & 27.9 \\
\hline Own ill health or disability & 3.9 & 6.0 \\
\hline Racial discrimination & 0.7 & 2.4 \\
\hline Age & 3.1 & 6.8 \\
\hline Other & 10.3 & 13.0 \\
\hline Total with difficulties & 87.8 & 90.9 \\
\hline No difficulties reported & 8.6 & 6.1 \\
\hline
\end{tabular}

a. The difference between remote and non-remote respondents is statistically significant at the $5 \%$ level. Source: Customised cross-tabulations from the 2002 NATSISS

Table 14.4 depicts respondents' perceptions of their main difficulty in finding work with a breakdown contrasting remote and non-remote people. Again, there is some useful data that emerges from the question. Transport problems to reach distant work sites was a more significant problem for people in non-remote areas, with nearly 16 per cent reporting this was their main difficulty in finding work. Most people in remote areas cited a lack of jobs over all other reasons as the primary problem in finding work. Nearly 30 per cent of remote respondents said there were no jobs at all and another 18 per cent said there were no jobs in the local area or in their line of work. This rate was significantly higher than among non-remote people, for whom a lack of education and training was the primary problem.

Table 14.5. Indigenous persons aged 15 years or over, whether attended vocational training, by remoteness, Australia, 2002

\begin{tabular}{|c|c|c|c|c|c|}
\hline \multirow[t]{2}{*}{$\begin{array}{l}\text { Vocational training (in last } 12 \\
\text { months) }\end{array}$} & $\begin{array}{r}\begin{array}{r}\text { Non-remote } \\
\text { female }\end{array}\end{array}$ & $\begin{array}{r}\text { Non-remote } \\
\text { male }\end{array}$ & $\begin{array}{r}\text { Remote } \\
\text { female }\end{array}$ & Remote male & $\begin{array}{r}\text { Significance } \\
\text { test }\end{array}$ \\
\hline & $\%$ & $\%$ & $\%$ & $\%$ & \\
\hline Attended & 26.6 & 34.1 & 16.7 & 23.4 & $\begin{array}{r}\text { non-remote }^{a} \\
\text { remote }^{\text {a }} \\
\text { female }^{b} \\
\text { male }^{b}\end{array}$ \\
\hline Did not attend & 73.4 & 65.9 & 83.3 & 76.6 & $\begin{array}{r}\text { non-remote } \\
\text { remote }^{a} \\
\text { female }^{\mathrm{b}} \\
\text { male }^{\mathrm{b}}\end{array}$ \\
\hline
\end{tabular}

a. The difference between male and female respondents is statistically significant.

b. The difference between remote and non-remote respondents is statistically significant.

Source: Customised cross-tabulations from the 2002 NATSISS 
Obviously, the lack of education and training is a critical problem, particularly among non-remote people. Table 14.5 provides a closer look at people's experiences with vocational training, focusing on people in non-remote and remote areas who attended vocational training of some sort in the previous 12 months. Overall, the data show that men in both remote and non-remote areas were more likely to attend training than women, and people living in non-remote areas were more likely to attend training than those in remote areas. Higher attendance in vocational training in non-remote areas is coupled with the strong perception that individuals in non-remote areas lack the necessary education and training or skills. One might ask whether there is a gap between the training offered and the training needed, but the data do not provide evidence to answer this question.

It is often said with a large degree of sarcasm by both Indigenous and non-Indigenous people that Indigenous Australians are the most highly trained workforce in the country, yet that training rarely leads to jobs. Nevertheless - as Table 14.6 shows - when asked, people overwhelmingly affirm that their training experiences are useful. More than four out of five remote and non-remote males and females indicated they have used their training. It is worth noting, as well, that the question asked was not a vague question like 'was the training useful', but instead it asked 'Have you used the information or skills you got from the training'?

Table 14.6. Indigenous persons aged 15 years or over, whether used vocational training, by remoteness, Australia, 2002

\begin{tabular}{lrrrrr}
\hline Was training used? & $\begin{array}{r}\text { Non-remote } \\
\text { female } \\
\%\end{array}$ & $\begin{array}{r}\text { Non-remote } \\
\text { male } \\
\%\end{array}$ & $\begin{array}{r}\text { Remote Remote male } \\
\text { female } \\
\%\end{array}$ & $\begin{array}{r}\text { Significance } \\
\text { test }\end{array}$ \\
\hline Used training & 86.8 & 82.8 & 86.0 & 92.3 & remote $^{\text {a }}$ \\
& & & & & male $^{\text {b }}$ \\
Did not use training & 13.2 & 17.2 & 14.0 & 7.7 & \\
\hline
\end{tabular}

a. The difference between male and female respondents is statistically significant.

b. The difference between remote and non-remote respondents is statistically significant.

Source: Customised cross-tabulations from the 2002 NATSISS

The 2002 survey enables an even closer exploration of the reported value of vocational training. In the survey, people who said they used the training were asked the follow-up question, 'How was the training used?'. Table 14.7 summarises the responses to that question and shows that the vast majority, again in both non-remote and remote areas, male and female, said they used it 'for work'. Another 10 per cent or so said they used it 'to get a job'.

Interestingly, the 1994 NATSIS recorded other responses to questions about the use of training, including 'for personal growth' and 'hobby'. Those options do not appear on the 2002 survey and presumably are subsumed under 'other'. This streamlining, if that is what accounts for the change, is unfortunate, since 
more people cited personal growth as a use in the 1994 survey than 'to get a job' (about 30 per cent). It appears that the changes to the 2002 survey provide disappointingly less insight into the myriad reasons people engage in study.

Table 14.7. Indigenous persons aged 15 years or over, how vocational training was used, by remoteness, Australia, 2002

\begin{tabular}{lrrrrr}
\hline How training was used & $\begin{array}{r}\text { Non-remote } \\
\text { female }\end{array}$ & $\begin{array}{r}\text { Non-remote } \\
\text { male }\end{array}$ & $\begin{array}{r}\text { Remote } \\
\text { female } \\
\%\end{array}$ & $\begin{array}{r}\text { Remote male } \\
\%\end{array}$ & $\begin{array}{r}\text { Significance } \\
\text { test }\end{array}$ \\
\hline Used for work & 75.5 & 69.1 & 74.7 & 81.4 & male \\
Used to get a job & 12.2 & 11.3 & 10.7 & 8.0 & 1.4 \\
Used, other & 3.5 & 1.7 & 3.7 & \\
\hline
\end{tabular}

a. The difference between male and female respondents is statistically significant.

b. The difference between remote and non-remote respondents is statistically significant.

Source: Customised cross-tabulations from the 2002 NATSISS

The real power in surveys like NATSISS, from my perspective, is the possibility of exploring the patterns of relationships between variables. Table 14.8 cross-tabulates a handful of social characteristics with data on school completion and qualification. The questions that animate the analysis presented in this table, are the following: 'What is the place of the western-educated person in Indigenous communities?'. 'Are they different as a result of their western education and, if so, how do they compare to their friends, family and other 'non-western-educated' or 'less-western-educated' members of their community? The notion of 'western-educated' obviously requires some explanation. Firstly, given that there are few-if any-Indigenous individuals in Australia today who have not come in contact with western schools or other education and training institutions, the notion of a 'western-educated' individual assumes a continuum of experience and knowledge. Individuals who are 'western-educated', as I am using the term, have typically successfully engaged with and reached a recognised level of competency (completion of primary or secondary schooling and/or a qualification) in a government or non-government school or other educational institution. For the purposes of this analysis, I am defining a 'western-educated person' as a person towards one end of the continuum: from those with some secondary education through to those who have gained a non-school qualification. These are people who have some degree of facility with English literacy and numeracy, who are recognised by other Indigenous people as having particular skills, and who can thus move with some confidence within the structures and expectations of mainstream institutions. 
Table 14.8. Indigenous persons aged 15 years or over, non-school qualification by highest year of school completed by selected characteristics, Australia, 2002

\begin{tabular}{|c|c|c|c|c|c|}
\hline & \multicolumn{5}{|c|}{ Non-school qualification? } \\
\hline & \multicolumn{4}{|c|}{ No } & Yes \\
\hline & Year 9 or below & Year 10 or 11 & Year 12 & Total & Total \\
\hline & $\%$ & $\%$ & $\%$ & $\%$ & $\%$ \\
\hline $\begin{array}{l}\text { Current daily } \\
\text { smoker }\end{array}$ & 57.3 & 53.2 & 40.7 & 53.3 & 45.7 \\
\hline Employed CDEP & 13.2 & 15.8 & 13.4 & 14.2 & 9.5 \\
\hline $\begin{array}{l}\text { Employed } \\
\text { non-CDEP }\end{array}$ & 17.4 & 32.4 & 52.7 & 28.2 & 53.5 \\
\hline $\begin{array}{l}\text { Not in the labour } \\
\text { force }\end{array}$ & 57.5 & 36.1 & 22.7 & 44.3 & 23.9 \\
\hline $\begin{array}{l}\text { Unable to raise } \\
\$ 2000 \text { within a } \\
\text { week for } \\
\text { something } \\
\text { important }\end{array}$ & 71.6 & 56.5 & 40.0 & 61.3 & 38.8 \\
\hline $\begin{array}{l}\text { Cannot, or often } \\
\text { has difficulty, } \\
\text { getting to the } \\
\text { places needed }\end{array}$ & 16.7 & 10.4 & 9.5 & 13.3 & 8.4 \\
\hline $\begin{array}{l}\text { Had undertaken } \\
\text { voluntary work in } \\
\text { last } 12 \text { months }\end{array}$ & 16.7 & 23.3 & 33.1 & 21.6 & 42.0 \\
\hline
\end{tabular}

Source: ABS (2004c: Table 7)

Acknowledging that this analysis is exploratory, note first that the contrasts between those with and those without non-school qualifications are statistically significant for each of these social characteristics. In other words, statistical analysis suggests that individuals in these two categories are different from one another in each of the characteristics. There is a great deal to ponder in these results but space is limited here, so I would simply like to highlight some of the findings and put forth some propositions. Firstly, there is a clear association between smoking and lower educational attainment. Indeed, the proportion of smokers declines as the number of completed years of secondary education increases. If smoking has a social cost (e.g. in economic terms or in terms of an individual's or a family's health), then it appears that educated individuals are less likely to suffer those costs as, presumably indirectly, are members of their families.

The next three characteristics in Table 14.8 reveal an association between employment and education. First, relatively lower levels of education correlate with a greater likelihood of employment in CDEP while higher levels of education and non-school qualification are strongly associated with employment outside the CDEP scheme. Similarly, those with the least education are by far the most likely to have withdrawn from the labour force. Education is strongly associated with the ability to alleviate financial stress. When asked if they could raise $\$ 2000$ within a week for something important, over 70 per cent of respondents who 
had completed only Year 9 or below said they could not. On the other hand, over 60 per cent of individuals with a non-school qualification said they could. Increased levels of education appear to be associated with increased domestic financial agility, in the sense that these people are most likely to be able to raise money at short notice. Similarly, people who are more educated would appear to be better placed to draw on whatever resources they must to get to places they need to reach. For example, only about 8 per cent of people with non-school qualifications said they cannot or often have difficulty getting to places they need to go, while double that proportion of individuals who had attained education at Year 9 or below had such difficulties.

Finally, and most intriguingly, there appears to be a strong association between education and undertaking voluntary work. In the context of the survey, the notion of voluntary work appears in a question about volunteering work for a range of different organisations, not in caring for family or other such 'voluntary work'. While only about 17 per cent of individuals with education levels at Year 9 or below engaged in voluntary work, 42 per cent of individuals with non-school qualifications did so. While this result deserves more analysis than is possible here, one could interpret this to mean that people who have invested in education - who, as economists might say, are engaged in 'human capital acquisition' - have an increased tendency to re-invest in their communities through voluntary work. That proposition is interesting, in that it flies in the face of the often-stated perception that as Indigenous people gain education (and income) they are in increased danger of disconnecting from the Indigenous community. Such are some of the important questions the NATSISS raises and might allow us to answer or at least explore.

\section{NATSISS, education and training beyond 2002: is it worth the trouble?}

Unlike 1994, today we have mountains of increasingly good data depicting the experience of Indigenous Australians with education and training. For example, relevant data are collected by:

- the Commonwealth Department of Education, Science and Training (DEST)

- the Ministerial Council on Education, Employment, Training and Youth Affairs (MCEETYA)

- the Commonwealth Department of Employment and Workplace Relations (DEWR)

- the National Centre for Vocational Education Research (NCVER)

- the Australian Council for Education Research (ACER), and

- all the various States and Territories.

Many of these are administrative data sets useful in assessing and monitoring the delivery and outcomes of programs. The DEST data are particularly detailed, 
with omnibus statistics now assembled annually in the National Report to Parliament. While there are always issues about access and data quality, there is currently more education and training data available today than ever before.

Data are generally of higher quality now, and some agencies and departments appear to be opening up and welcoming collaboration and analysis in ways that were in the past inconceivable. But in regard to NATSISS, some important data have been lost in streamlining the education and training questions. Much of what we now have in NATSISS (and presumably will get again in 2008) is identical to what we can get from DEST or NCVER on an annual basis.

Comparing the 1994 NATSIS with the 2002 NATSISS, it appears the focus has shifted and the education and training components of the survey seem to favour easy questions over difficult ones. What was lost was the attempt to acquire a range of attitudinal data. It should be noted that many of these questions were included in the 1994 survey at the request of Indigenous people who were concerned with a range of important social justice and cultural issues. These questions included things like, 'Are you happy with your child's education? Has your child been taught Indigenous studies or an Indigenous language? Do they have an Indigenous teacher? Do you feel welcome in your child's school? Are you involved in decision making at the school? Would you prefer a community-controlled school?'. From one perspective these are all, one could argue, questions which are politically unsavoury. They highlight what the education system is (or is not) providing Indigenous families while the 2002 questions focus on what may be the outcome of that provision: the level of participation. Yet, without insight into the former, it is too easy to blame the Indigenous families for low levels of participation.

One must acknowledge that the attitudinal questions did not work well in 1994 and I was one who criticised the questions and the data they yielded (Schwab 1996). Yet I'm sorry to see the baby tossed out with the bathwater and I would hope the ABS will have another look at how to get at those important aspects of the Indigenous experience. When the most common reason given for leaving school is 'I didn't like school', it seems we should be redoubling our efforts to understand why. And perhaps we should be asking more about the experience of school and not just about patterns of participation.

Even in its pared down form, the 2002 NATSISS provides a rich data set that enables an exploration of the linkages among a broad range of variables that simply are not available in other surveys. It is in that way that the survey is such a powerful tool. While education and training data are increasingly accessible from a wide range of sources, there is no other robust data set that enables researchers to explore, for example, how education might relate to health, or training to internet use, or non-school qualification to arrest. NATSISS is - and should be-much more than a device to track outcomes. There are enough of 
those sorts of data sets already. It should, rather, assist movement beyond the 'what' questions to the more difficult and ultimately important 'why' questions. It should be a tool for helping researchers, policy makers and communities explore what we can and should do to address the needs of Australia's most disadvantaged citizens. In that way, it would be worth the trouble. 